\title{
MANAJEMEN PERUBAHAN PADA PERUSAHAAN KELUARGA: STUDI KASUS PT RODA BAHARI
}

\author{
Arie Wibowo Irawan \\ Dosen Tetap Fakultas Ekonomi Universitas Pakuan
}

\begin{abstract}
ABSTRAK
Perusahaan keluarga adalah penggerak utama perekonomian Indonesia. Sektor ini memberikan kontribusi sekitar 82,44\% dari total PDB Indonesia. Jumlah bisnis keluarga adalah sekitar 99\% dari total usaha kecil menengah (UKM) di Indonesia. Namun hanya sebagian kecil bisnis keluarga yang dapat bertahan dan scalling up. PT. Roda Bahari yang menjadi objek penelitian ini adalah salah satu bisnis keluarga yang berlokasi di Bogor. Tujuan dari penelitian ini adalah untuk menganalisis proses manajemen perubahan dan siklus sebuah perusahaan. Penelitian ini penting untuk merumuskan dan mempersiapkan diri pada setiap tahapan proses transformasi yang dibutuhkan oleh PT. Roda Bahari dalam rangka menciptakan sebuah entitas bisnis profesional. Metode analisis yang digunakan adalah deskriptif dan jenis data kualitatif. Pengumpulan data kualitatif dilakukan dengan wawancara dan Focus Group Discussion (FGD). Jumlah responden adalah 10 orang termasuk stakeholder, manajemen puncak, dan staf. Dalam mengidentifikasi perubahan yang telah terjadi digunakan Lewin's Three Step Model dan untuk mengidentifikasi perubahan yang akan dilakukan digunakan Kotter Eight Stage Change Process. Hasilnya menunjukkan bahwa usaha keluarga ini berada dalam managing phase yang ditandai dengan pertumbuhan dan mulai ada keterlibatan keluarga besar dalam perusahaan. Guna bergerak ke fase berikutnya (transformation phase), PT. Roda Bahari harus menerapkan manajemen perubahan. Proses manajemen perubahan ini, membutuhkan agent of change yang berasal dari internal perusahaan. Agent of change ini harus memiliki kompetensi, terlibat dalam hari ke hari, dan juga memiliki akses strategis untuk pemilik. Berdasarkan identifikasi menggunakan teori Kotter, diketahui bahwa PT. Roda Bahari harus membuat perubahan pada struktur organisasi, budaya perusahaan, dan kebijakan perusahaan dalam transformation phase.
\end{abstract}

Kata Kunci: Perusahaan Keluarga, Manajemen Perubahan, Siklus Perusahaan

\begin{abstract}
Family business is the main driving of Indonesian economy. This sector contribute about 82,44\% of total Indonesian GDP. The number of family business is about 99\% of total Small Medium Enterprise (SME) in Indonesia. However, only a little family business can survive and scalling up. PT. Roda Bahari that become object of this research is one of the family business. The aim of this research is to analyze change management process and company cycle. This research is important to formulate and prepare for every stage of the transformation process required by PT. Roda Bahari in order to create a professional business entity. The study was conducted in Bogor. The method analysis used is descriptive and the type of data is qualitative. Qualitative data collection was done by interviews and FGD (Focus Group Discussion). The number of responden are 10 person including stakeholder, top management, and staff. To identify the changes that has occured was used Lewin's Three Step Model and to identify the changes that will be done was used Kotter Eight Stage Change Process. The result shows that this family business currently in managing phase indicated by company's growth and involvement of the extended family. In order to move to the next phase (transformation phase), PT. Roda Bahari should apply change management. This change management process, require internal agent of change, who has competency, involve in day to day business, and also has strategic access to owner. Based on the identification using Kotter theory, it is known that PT. Roda Bahari should make change in organizational structure, corporate culture, and company policies toward transformation phase.
\end{abstract}

Key Words: Family Business, Change Management, Company Cycle 


\section{Pendahuluan}

Dewasa ini, roda pembangunan Indonesia sebesar 83\% digerakkan oleh swasta dan masyarakat. Dari proporsi $83 \%$ tersebut, ternyata $99 \%$ merupakan usaha UMKM dan $1 \%$ sisanya merupakan usaha dengan skala besar. Hal yang menarik adalah ternyata $96 \%$ perusahaan yang ada di Indonesia merupakan perusahaan keluarga (Kemenkop dan UKM 2012). Berdasarkan data Biro Pusat Statistik, perusahaan keluarga di Indonesia merupakan perusahaan swasta yang mempunyai kontribusi besar terhadap Produk Domestik Bruto yaitu mencapai 82,44 persen. Ironisnya dari sekian banyak perusahaan keluarga ini, hanya sebagian kecil saja yang mampu bertahan dan bertransformasi menjadi perusahaan besar (scaling up). Hasil survey terhadap 87 perusahaan keluarga di Indonesia, menunjukkan bahwa $78 \%$ perusahaan dipegang oleh generasi pertama, sementara generasi kedua dan seterusnya hanya $15 \%$ dan $7 \%$. Dengan begitu banyaknya masalah internal yang ada, pada akhirnya memunculkan mitos bahwa "generasi pertama membangun perusahaan, generasi kedua menikmati kekayaan, dan generasi ketiga menghancurkan".

PT. Roda Bahari yang menjadi objek dalam penelitian ini merupakan sebuah perusahaan keluarga dengan skala UMKM yang bergerak pada bidang kelautan dan perikanan. Ruang lingkup usaha yang dijalankan oleh PT. Roda Bahari meliputi konsultan, trading, serta produksi sarana dan prasarana pendukung bidang kelautan dan perikanan. Pada awal tahun 2012, melalui sebuah pertemuan keluarga, semua anggota keluarga sepakat untuk menjalankan usaha dalam kerangka kerja yang formal, berbadan hukum, serta profesional (PT. Roda Bahari). Keputusan ini merupakan keputusan solutif terhadap berbagai permasalahan yang terjadi selama bertahun-tahun. Seiring dengan berjalannya bisnis PT. Roda Bahari, pihak manajemen mulai menyadari bahwa setelah perusahaan resmi berbadan hukum, maka tugas selanjutnya adalah bagaimana membuat perusahaan dapat berdaya saing dan berkelanjutan. Salah satu langkah kongkrit yang dapat dilakukan adalah dengan melakukan change management.

\section{Tinjauan Pustaka}

Utomo (2009) dalam kajiannya menyebutkan bahwa dibutuhkan analisis eksternal dan internal untuk melakukan transformasi perusahaan keluarga dari sebuah Family Business Enterprise (FBE) menjadi Family Owned Enterprise (FOE). Isu internal diarahkan untuk mengidentifikasi keunggulan yang dimiliki oleh perusahaan untuk dibandingkan dengan pesaing dalam industri untuk menilai ada atau tidaknya Gap. Sedangkan isu eksternal, penelitian ini diarahkan untuk menyusun sebuah marketing plan guna memenuhi tuntutan industri akan datang. Purhantara (2009) menyimpulkan faktor eksternal dan internal mempengaruhi organisasi untuk melakukan suatu perubahan. Langkah strategis mengimplementasikan manajemen perubahan pada mengembangkan organisasi dapat ditempuh dengan beberapa langkah, yaitu: perubahan pada tingkat individu, perubahan pada tingkat kelompok, dan perubahan pada tingkat organisasi. Cater dan Schwab (2008) mendefinisikan turnaround strategy sebagai seperangkat konsekuensial, direktif, keputusan dan tindakan yang ditargetkan jangka panjang pada pembalikan krisis yang dirasakan mengancam kelangsungan hidup perusahaan. Strategi yang digunakan mencakup perubahan top management, menggunakan jasa tenaga ahli eksternal, dan penghematan 
organisasi. Jaffe (2005) menyimpulkan keluarga dapat menerapkan dua fungsi/peran untuk membatasi dunia keluarga dan dunia usaha, yakni: (1) dewan anggota keluarga yang dapat memfasilitasi kehendak keluarga dalam kaitannya dengan bisnis (2) Direksi yang bertugas mengurusi realitas bisnis, membantu bisnis mengembangkan dan selalu berinovasi.

Amin (2009) menyatakan bahwa selama proses change management terdapat dua kekuatan yang saling bertentangan, yaitu kekuatan yang mendukung perubahan (Driving Forces) dan kekuatan yang menentang perubahan (Restraining Forces). Bila jumlah kekuatan yang medukung perubahan lebih dominan dibandingkan jumlah kekuatan yang menentang perubahan, maka perubahan akan lebih mudah dilakukan. Maharani (2009) dalam penelitian mengenai perubahan di perusahaan keluarga tradisional menyatakan bahwa perusahaan keluarga yang masih tradisional dan belum mengenal struktur yang jelas dalam chain of command nya mungkin akan mengalami kesulitan dalam proses perubahan apapun. Namun, jika perubahan terjadi maka efeknya pun akan sangat besar, terutama untuk kelestarian bisnis yang menitikberatkan pada kerjasama antara keluarga tersebut. Xiongwei (2009) dalam jurnalnya memuat tentang pentingnya manajemen perubahan bagi kelangsungan dan perkembangan organisasi. Semakin efektif Anda menangani perubahan, semakin besar kemungkinan Anda tumbuh dan berkembang. Namun demikian, banyak terjadi kegagalan dalam manajemen perubahan. Perubahan organisasi sendiri merupakan aktivitas yang sangat kompleks; satu kesalahan kecil dalam manajemen perubahan dapat mengakibatkan kegagalan perubahan organisasi. Jurnal ini berusaha menerangkan sebab-sebab kegagalan strategi manajemen perubahan dari 4 perspektif (kepemimpinan, budaya, masalah SDM dan respon cepat) yang merupakan faktor-faktor utama dalam keberhasilan dan kegagalan manajemen perubahan. $\mathrm{Li}$ Liu \& Xinde (2014) menyatakan bahwa untuk mencapai pembangunan berkelanjutan jangka panjang dan bersaing di pasar global, perusahaan keluarga Cina harus memulai inovasi kognisi dan inovasi struktur, misalnya, dari struktur organisasi yang tradisional dikembangkan menjadi sistem perusahaan modern. Konsep Inovasi adalah berisi ide-ide maju dan konsep berpikir ke depan. Ini adalah prasyarat untuk kelangsungan hidup dan pengembangan unit usaha. Untuk mencapai manajemen modern, bisnis keluarga harus melakukan upaya untuk mengatasi kepentingan yang tidak memadai dan jelas dari semua pihak melalui membedakan aset keluarga dari perusahaan.

Yudhaningsih (2011) meyatakan perubahan organisasi berperan terhadap efektivitas kerja yang berarti bahwa setiap peningkatan perubahan organisasi satu satuan akan berpengaruh terhadap peningkatan efektivitas kerja. Tidak semua pegawai dapat menyesuaikan diri terhadap perkembangan organisasi maka setiap perubahan organisasi selalu menghadapi berbagai masalah, terutama adalah penolakan atas perubahan (resistance to change). Penolakan atas perubahan tidak selalu muncul dalam bentuk standar (eksplisit) dan segera misalnya mengajukan protes, mengancam mogok, demontrasi dan sejenisnya tetapi juga ada penolakan secara eksplisit dan lambat laun seperti loyalitas pada organisasi menurun, 
motivasi berkurang, kesaahan kerja meningkat, kedisipilnan berkurang dan lain-lain. Kultur atau kebiasaan memiliki implikasi terhadap kecepatan dan ketepatan dalam penyelesaian pekerjaan. Budaya organisasi yang sehat berpengaruh terhadap peningkatan efektivitas kerja.

\section{Metodologi Penelitian}

Penelitian menggunakan metode deskriptif dalam bentuk studi kasus. Jenis data yang digunakan adalah data kualitatif dengan teknik pengumpulan data melalui observasi dan studi pustaka. Melalui metode deskriptif akan diperoleh dua buah output. Output pertama, akan diperoleh sebuah peta stakeholder yang komprehensif meliputi karakteristik, peran, dan kepentingan setiap stakeholder. Peta stakeholder ini digunakan sebagai entry point untuk melakukan change management. Output kedua, berupa gambaran yang utuh terkait proses change management, baik yang sudah terjadi maupun yang akan dilaksanakan.

Identifikasi terhadap perubahan yang sudah terjadi dilakukan melalui teori Lewin's Three Step Model, dengan tahapan: (1) Unfreezing the status quo, (2) Movementtothenewstate, Refreezing. Sedangkan untuk menentukan langkah-langkah perubahan yang akan dilaksanakan mengikuti kerangka kerja teori Kotter Eight Stage Change Process, dengan tahapan: (1) Increase Urgency, (2) Build The Guiding Team, (3) Get The Right Vision, (4) Communicating for Buy In, (5) Empower Action, (6) Create Short Term Win, (7) Don't Let Up, (8) Make change stick.

\section{Hasil Dan Pembahasan}

PT. Roda Bahari secara resmi baru berdiri pada April 2012, namun kegiatan usaha dalam bentuk jasa konsultansi sudah dirintis semenjak tahun 1986, dimana saat itu owner adalah pengajar untuk bidang Kelautan dan Perikanan sehingga sering dipercaya sebagai tenaga ahli dan pengkaji untuk proyekproyek pemerintah maupun swasta. Seiring dengan pengalaman selama bertahun-tahun, terbentuklah image dan kredibilitas owner. Hal tersebut kemudian menjadi alasan didirikannya perusahaan sekaligus menjadi entry point penentuan fokus bisnis. Pada awal kegiatan usaha, owner hanya dibantu oleh beberapa orang karyawan. Usaha saat itu berjalan tanpa perencanaan dan pengawasan. Operasional kerja dan keuangan dilakukan tanpa aturan baku dan pengawasan yang benar.

Dua tahun semenjak berdirinya perusahaan, telah terjadi beberapa perubahan besar pada manajemen. Masuknya generasi kedua di posisi kunci perusahaan membawa dampak positif bagi perkembangan dan kelanjutan usaha. Beberapa pembenahan yang mendasar diantaranya adalah merumuskan rencana kerja yang relatif sederhana, melakukan dan diversifikasi usaha, memperbaiki struktur organisasi perusahaan, merekrut karyawan baru sesuai dengan kebutuhan organisasi, dan menciptakan budaya kerja yang baik. 


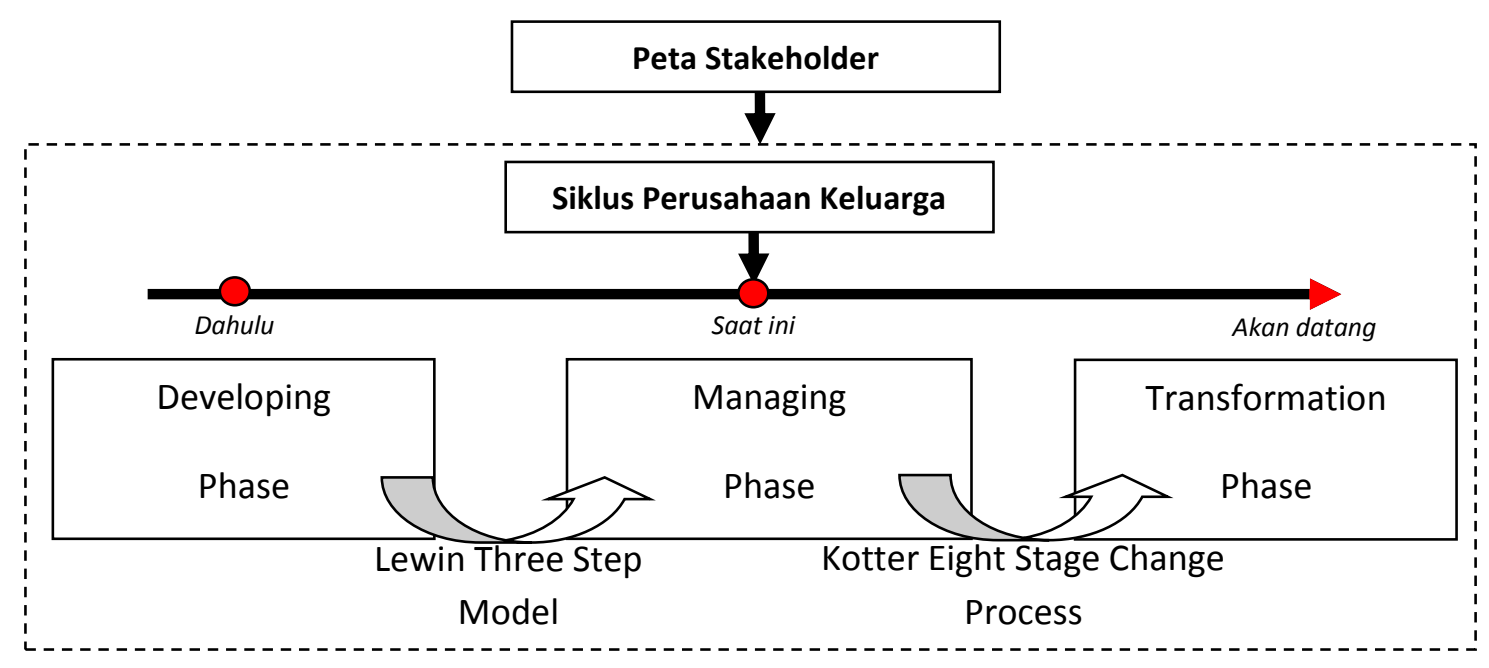

Kini bisnis mulai menampakkan kemajuan, PT Roda Bahari mengalami peningkatan nilai omzet dan pendapatan. Perubahan pembagian fungsi dan tanggung jawab perusahaan membentuk hierarki dimana terdapat manajemen tingkat atas, menengah, dan bawah. Struktur organisasi PT. Roda Bahari kini terdiri dari:

- Owners, merupakan perintis usaha atau bisnis keluarga

- Top Management, terdiri dari direktur yang juga masih memiliki hubungan keluarga dengan owners

- Middle Management, terdiri dari manager dan supervisor. Pada struktur organisasi ini terdiri dari para professional (bukan anggota keluarga) yang sengaja dipekerjakan oleh perusahaan untuk memonitor dan mengevalusasi pekerjaan setiap harinya

- Staff, merupakan karyawan perusahaan yang mengerjakan day to day activities dan juga menjalankan fungsi supporting

- Associate, terdiri dari para dosen bekerja berdasarkan proyek basis yang membantu perusahaan dalam bidang konsultan

Merujuk pada klasifikasi skala usaha UMKM, PT. Roda bahari tergolong perusahaan keluarga dengan skala kecil. Dengan jumlah aset Rp 50 Juta - Rp 500 juta (diluar tanah dan bangunan) dan omset Rp 300 Juta - Rp 2,5 Miliar per tahun. Saat ini terdapat tiga bisnis dari PT. Roda Bahari, yakni konsultan, trading rumput laut Gracilaria sp., dan produk inovasi. Ketiga bisnis ini masih dalam tahap "embrionik", dimana mayoritas usahanya masih belum stabil. Selain itu, ketiga bisnis tersebut belum secara legal terdaftar (berbadan hukum). Rencananya, PT.Roda Bahari akan membuat perusahaan baru yang berbadan hukum untuk bisnis yang dinilai cukup mapan, profitable, dan berkesinambungan.

Langkah pertama dalam melakukan perubahan adalah menelaah peta stakeholder. Melalui peta stakeholder ini, kita dapat melihat karakteristik, peran, dan kepentingan setiap stakeholder. Di sisi lain, peta stakeholder juga berfungsi untuk mengetahui apakah otoritas dan kekuasaan berada dalam satu satu kesatuan atau terpisah pada perusahaan.

a) Mr. A (Komisaris Utama-Pendiri, Owner)

Termasuk kedalam "kategory C" yang mempunyai power yang tinggi untuk mengambil keputusan strategis dan memberikan arah kebijakan (decision maker). Namun Mr. A cenderung memiliki interest yang rendah karena dapat dikatakan tidak memiliki motif ekonomi yang dominan dalam menjalankan usaha ini. Langkah dan perlakuan yang 
sesuai untuk kategori ini adalah "keep satisfied" dengan memberikan output perusahaan yang memuasakan (tangible dan intangible).

b) Mrs. B dan Mrs. C (Pemegang Saham-Anak Owner)

Termasuk kedalam "kategori B", dimana yang bersangkutan memiliki power yang rendah, namun interest serta predictability yang relatif tinggi. Baik Mrs. B dan Mrs. C tidak mempunyai keterlibatan terhadap aktivitas bisnis setiap harinya karena kesibukan masing-masing yang tidak berkaitan secara langsung dengan perusahaan.Langkah dan perlakuan yang sesuai untuk kategori ini adalah "keep informed".

c) Mrs. D (Direktur Utama-Anak Owner)

Termasuk kedalam "kategori A", dimana yang bersangkutan memiliki power, interest, predictability yang rendah. Mrs. D bisa dikatakan hanya menjabat direktur secara struktural, sedangkan secara fungsional tidak terlibat sama sekali. Langkah dan perlakuan yang sesuai untuk kategori ini adalah "usaha minimal".

d) Mr. E (Direktur OperasionalMenantu Owner)

Termasuk kedalam "kategori D", dimana yang bersangkutan memiliki power, interest, predictability relatif tinggi. Peran Mr. E dalam perusahaan sangatlah vital karena ia merupakan enabler sekaligus agent of change dalam perusahaan. Kebutuhan perusahaan akan eksistensi Mr. E bukan didasarkan pada faktor kekeluargaan melainkan lebih kepada unsur profesionalisme. Hal ini tercermin dari setiap keputusan yang diambil pasti memiliki reasoning yang objektif dan logis. Mr. E mempunyai akses yang baik kepada komisaris utama yang dalam hal ini juga merupakan owner. Pendapatnya biasanya didengar dan dipertimbangkan. Langkah dan perlakuan yang paling cocok untuk kategori ini adalah "key player" karena perilaku yang ditimbulkan akan berdampak sangat kuat namun dapat diduga.

e) Mrs. F (Penasehat 1 Non strukturalIstri Owner)

Termasuk kedalam "kategori C" yang mempunyai power yang tinggi terhadap arah kebijakan perusahaan. Dalam aktivitas operasional bisnis sehari-hari, Mrs. F relatif memiliki interest dan predictability yang rendah. Mrs. F sering berperan sebagai influencer yang sangat mungkin mempengaruhi sebuah keputusan akhir, walaupun secara struktural tidak masuk dalam jajaran manajemen. "Keep Satisfied" dalam hal ekonomi (profit and loss) dianggap sebagai perlakuan yang paling sesuai.

f) Mr. G (Penasehat 2 Non structuralAdik ipar owner)

Termasuk kedalam "kategori B", dimana yang bersangkutan memiliki power yang rendah namun tingkat interest, predictability yang tinggi. Langkah dan perlakuan yang sesuai untuk kategori ini adalah "Keep Informed" yang dilakukan secara regular dinilai akan memuaskan Mr. G. Walaupun Mr. G berada tidak ada dalam jajaran manajemen, namun dalam mengambil keputusan bisnis perusahaan selalu meminta pertimbangannya. 
g) Mr. $\mathrm{H}$ dan Mr. I (Manajer operasional dan Manajer keuanganNon anggota keluarga)

Termasuk kedalam "kategori B", dimana yang bersangkutan memiliki power yang rendah namun tingkat interest, predictability yang tinggi. Langkah dan perlakuan yang sesuai untuk kategori ini adalah "Keep Informed". Mr. H dan Mr. I berperan sebagai eksekutor suatu kebijakan perusahaan. Selain itu kedua manajer ini juga berperan untuk memberikan masukkan kepada direktur operasional.
PT. Roda Bahari tidak berada dalam satu kesatuan.

PT. Roda Bahari merupakan Family

Business Enterprise (FBE), dimana kepemilikan maupun pengelolaan dipegang oleh pihak yang sama, yaitu keluarga. Perusahaan keluarga tipe ini dicirikan oleh dipegangnya posisi-posisi kunci dalam perusahaan oleh anggota keluarga (Susanto 2002).

Tahapan-tahapan perusahaan keluarga menurut Susanto (2002) terdiri dari 4 fase sebelum mencapai titik stabilitas (established), yakni: developing phase, managing phase, transformation phase,

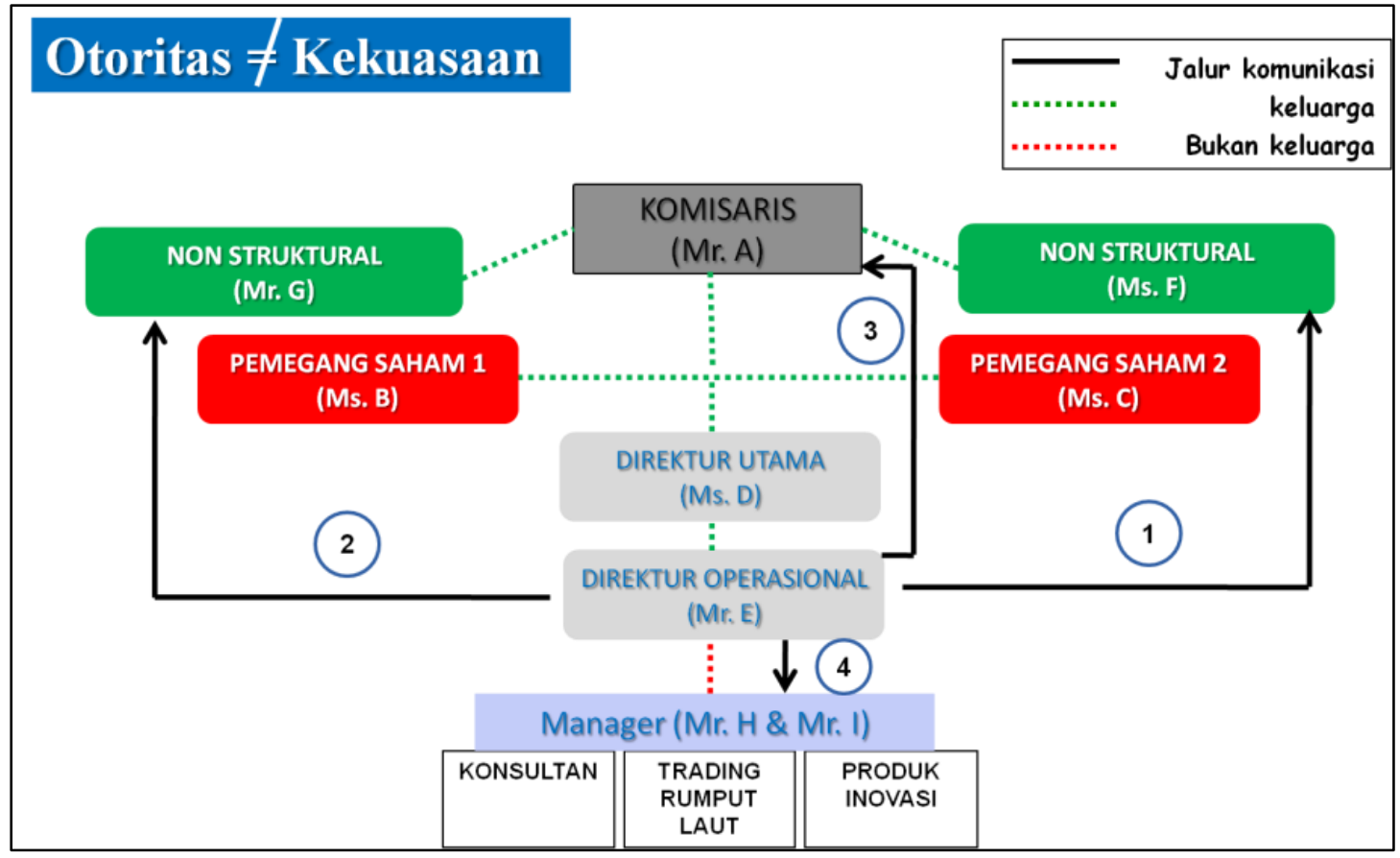

Merujuk pada peta stakeholder diatas, dapat diidentifikasi bahwa Mr. E selaku direktur operasional merupakan agent of change dalam proses change management, karena dinilai kompeten, terlibat langsung dalam day to day bisnis, serta memiliki akses yang cukup kepada pihak pengambil keputusan. Dalam proses pengambilan keputusan di PT. Roda Bahari sebagai perusahaan keluarga sangat dipengaruhi oleh anggota keluarga non struktural. Dengan kata lain, otoritas dan kekuasaan pada dan sustaining phase. Pada proses manajemen perubahan tahap 1, PT. Roda Bahari telah melalui satu tahapan perubahan dari developing phase menjadi managing phase. Untuk mengidentifikasi proses perubahan yang telah terjadi ini, digunakan teori FieldForce yang dicetuskan oleh Kurt Lewin. Adapun tahapan-tahapannya adalah sebagai berikut:

\section{a) Unfreezing the status quo}


Tujuan pada tahap unfreezing adalah untuk menciptakan sebuah kesadaran tentang sebuah perubahan. Dalam implementasinya, Mr. E selaku agent of change dan penggagas perubahan harus terlebih dahulu mengkomunikasikan idenya kepada Mrs. F. Walaupun berada diluar struktur perusahaan, perannyayang relatif dominan dalam keluarga sekaligus sebagai influencer utama untuk Mr. A merupakan critical point diterima atau ditolaknya sebuah perubahan.

Setelah mendapat approval dari Mrs. F, kemudian Mr. E mengkomunikasikan konsep ataupun gagasan baru tersebut melalui pertemuan formal (meeting internal keluarga) dan informal (diskusi ringan dalam santap pagi dan malam hari) kepada Mr. A, Mrs. B, Mrs. C, dan Mrs. D.

\section{b) Movement to the new state}

Pada tahap ini dapat dikatakan semua pihak dalam perusahaan sudah mulai bisa menerima gagasan baru dan relatif bisa "digerakkan".Pergerakkan atau perubahan yang dilakukan menjadikan perusahaan berada dalam masa transisi, dimana ditandai dengan ketidakpastian dan kekhawatrian. Masa transisi ini merupakan bagian tersulit karena biasanya memakan waktu dan tenaga yang banyak. Semua orang berjuang dengan realitas baru, perilaku baru, proses baru, dan cara berpikir baru. Oleh karena itu dibutuhkan komitmen manajemen dalam bentuk komunikasi dan dukungan terhadap objek perubahan, baik pada level atas maupun pada level bawah. Setiap perubahan pada kedua level ini selalu diinisiasi oleh Mr. E, dengan terlebih dahulu menyampaikan gagasannya terkait perubahan kepada Mrs. F dan Mr. G. Kedua pihak tersebut berupaya diyakinkan oleh Mr. E tentang arah perubahan dan beberapa hal yang fundamental.

Movement to the new state pada level atas, dilakukan oleh Mr. E melalui pertemuan informal. Objek perubahan pada level ini meliputi owner (Mr. A) dan top management (Mrs. B, Mrs. C, dan Mrs. D). Berikut ini beberapa perubahan yang telah dilakukan:

- Keterlibatan generasi kedua yang duduk dalam top management, sebelumnya hanya melibatkan generasi pertama

- Mulai ada pemisahan antara keuangan keluarga dan perusahaan, sebelumnya keuangan menjadi satu

- Sudah ada distribusi pendapatan keluarga dan perusahaan, namun karena pendapatan perusahaan masih relatif kecil maka seluruh pendapatan masih diditribusikan ke perusahaan. Sebagai contoh, adanya komitmen komisaris dan pemegang saham yang tidak menuntut return dalam jangka pendek

- Laporan keuangan saat ini ter-update secara rutin

- Pajak sudah mulai dilaporkan walaupun belum menyeluruh

Movement to the new state pada level bawah juga dilakukan oleh Mr. E melalui pertemuan formal (rapat mingguan dan bulanan) yang melibatkan seluruh karyawan sebagai objek perubahan. Berikut ini beberapa perubahan yang telah dilakukan: 
- Keterlibatan pihak luar sebagai karyawan baru melalui proses rekrutmen (wawancara), sebelumnya perusahaan melakukan rekrutmen hanya berdasarkan rekomendasi

- Mulai ada pembagian pekerjaan untuk setiap karyawan, sebelumnya karyawan melakukan multi jobdesk

\section{c) Refreezing}

Tahap ini melambangkan sebuah tindakan memperkuat dan menstabilkan setelah masa transisi (Movement to the new state). Tahapan ini akan membawa perusahaan pada norma baru untuk memastikan bahwa objek perubahan tidak akan kembali ke cara-cara lama.

\begin{tabular}{|c|c|c|c|}
\hline No & $\begin{array}{c}\text { Tahapan Manajemen } \\
\text { Perubahan }\end{array}$ & $\begin{array}{c}\text { Developing Phase } \\
\text { (Dahulu) }\end{array}$ & $\begin{array}{c}\text { Managing Phase } \\
\text { (Saat ini) }\end{array}$ \\
\hline 1 & Kategori perusahaan keluarga & $\begin{array}{l}\text { Family Business } \\
\text { Enterprise }\end{array}$ & $\begin{array}{l}\text { Family Business } \\
\text { Enterprise }\end{array}$ \\
\hline 2 & Keterlibatan generasi penerus & Generasi pertama & Generasi Kedua \\
\hline 3 & Konflik nilai dalam keluarga & Belum ada & Sudah ada (minim) \\
\hline \multirow[t]{5}{*}{4} & \multicolumn{3}{|l|}{$\begin{array}{l}\text { Kompetensi dan struktur } \\
\text { manajemen }\end{array}$} \\
\hline & a) Keterlibatan pihak luar & Sudah ada & Sudah ada \\
\hline & b) Proses rekrutmen & $\begin{array}{l}\text { Berdasarkan } \\
\text { rekomendasi }\end{array}$ & $\begin{array}{l}\text { Melalui proses } \\
\text { wawancara }\end{array}$ \\
\hline & c) Pembagian pekerjaan & Multi jobdesk & $\begin{array}{l}\text { Mulai ada pembagian } \\
\text { kerja }\end{array}$ \\
\hline & d) Jenjang karir karyawan & Belum ada & $\begin{array}{l}\text { Sudah ada (ruang lingkup } \\
\text { terbatas) }\end{array}$ \\
\hline \multirow[t]{4}{*}{5} & \multicolumn{3}{|l|}{ Kompensasi } \\
\hline & $\begin{array}{l}\text { a) Gaji komisaris dan } \\
\text { deviden pemegang } \\
\text { saham }\end{array}$ & $\begin{array}{l}\text { Komisaris tidak } \\
\text { menuntut return } \\
\text { jangka pendek }\end{array}$ & $\begin{array}{l}\text { Komisaris tidak menuntut } \\
\text { return jangka pendek }\end{array}$ \\
\hline & b) Gaji karyawan & Di bawah UMR & Berdasarkan UMR \\
\hline & c) Bonus karyawan & Belum ada bonus & $\begin{array}{l}\text { Bonus berdasar kan } \\
\text { sistem lembur }\end{array}$ \\
\hline \multirow[t]{5}{*}{6} & \multicolumn{3}{|l|}{ Aspek keuangan } \\
\hline & a) Laporan keuangan & $\begin{array}{l}\text { Sudah ada (belum ter- } \\
\text { update secara rutin) }\end{array}$ & $\begin{array}{l}\text { Sudah ada (ter-update } \\
\text { secara rutin) }\end{array}$ \\
\hline & b) Pelaporan pajak & Belum melaporkan & $\begin{array}{l}\text { Sudah melaporkan } \\
\text { (parsial) }\end{array}$ \\
\hline & $\begin{array}{l}\text { c) Pemisahan } \\
\text { keuangan keluarga } \\
\text { dan perusahaan }\end{array}$ & Masih menjadi satu & Mulai terpisah \\
\hline & 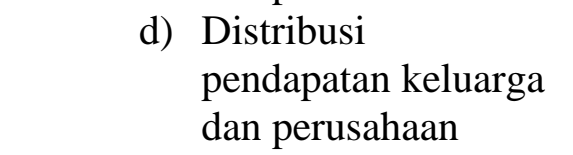 & $\begin{array}{l}\text { Belum ada } \\
\text { (tergabung) }\end{array}$ & $\begin{array}{l}\text { Sudah ada }(100 \% \\
\text { pendapatan untuk } \\
\text { perusahaan) }\end{array}$ \\
\hline 7 & Aturan baku perusahaan (SOP) & Belum ada & Sudah ada (belum tertulis) \\
\hline \multicolumn{2}{|c|}{$\begin{array}{l}\text { - Sudah ada aturan baku perusahaan } \\
\text { namun belum tertulis, seperti jam } \\
\text { datang dan pulang kantor }\end{array}$} & \multicolumn{2}{|c|}{$\begin{array}{l}\text { Norma-norma baru tersebut perlahan } \\
\text { namun pasti akan menjadi } \\
\text { budaya pebuah } \\
\text { melembaga. }\end{array}$} \\
\hline
\end{tabular}


Dalam mengimplementasikan tahap ini, Mr. E dibantu oleh Mr. A, Mrs. F, dan Mr. G. Proses refreezing pada PT. Roda Bahari dilakukan dengan pemberian penghargaan dan pengakuan secara individual, antara lain berupa:

- Penerapan insentif tetap bulanan yang lebih proporsional berdasarkan UMR, sedangkan dahulu dibawah UMR

- Penerapan insentif tambahan berupa sistem lembur (overtime), dibandingkan sebelumnya tidak ada pemberian bonus

- Menciptakan jenjang karir dalam ruang lingkup yang terbatas

Proses change management yang telah dilalui PT. Roda Bahari melalui Lewin's three step model dalam kerangka siklus perusahaan keluarga (developing phasemanaging phase), dapat dilihat pada tabel berikut.

Berdasarkan hasil yang diperoleh pada manajemen perubahan tahap 1, PT. Roda Bahari tergolong ke dalam kategori Family Business Enterprise (FBE) dan berada dalam managing phase. Kedepannya perusahaan berharap dapat mengembangkan diri menuju tahap selanjutnya, yaitu kategori Family Owned Enterprise (FOE) dan masuk ke dalam transformation phase. Beberapa karakteristik dari tahapan yang hendak dicapai ini diindikasikan dengan semakin banyaknya pihak eksternal (non keluarga) yang masuk, serta ditambah ruang lingkup bisnis yang semakin luas. Agar dapat merealisasikan hal tersebut diperlukan pondasi yang kuat. Ditengah dinamika bisnis yang semakin kompleks tersebut, owner beserta seluruh anggota keluarga yang notabene terlibat di perusahaan keluarga, perlahan namun pasti justru dituntut untuk mengurangi dominasinya. Disinilah letak kritikalnya, dimana sebagian besar perusahaan keluarga gagal bermetamorfosis untuk sampai pada tahap ini. Guna meminimalisir kegagalan tersebut, PT.
Roda Bahari harus dapat mengidentifikasi dan membandingkan indikator perubahan dari managing phase menjadi transformation phase.

Merujuk indikator-indikator diatas, maka dapat disusun sebuah rencana kerja nyata yang sistematis dalam rangka merealisasikan perubahan menuju transformation phase. Rencana kerja tersebut mengikuti Kotter Eight Stage Change Process. Menurut teori ini terdapat 8 tahap untuk menyusun sebuah change management, yakni:

\section{Increase Urgency}

Tahapan ini untuk memotivasi dengan cara mengkaji realitas pasar dan kompetisi, mengidentifikasi peluang dan membahas potensi krisis, sehingga timbul alasan yang baik untuk melakukan sesuatu yang berbeda.

Dalam konteks PT. Roda Bahari, Mr. E sebagai agent of change harus secara reguler memberikan informasi dan pemahaman kepada level atas (manajemen) dan juga pada level bawah (karyawan), terkait hal-hal yang seharusnya menjadi concern perusahaan untuk bisa terus berkembang.

Pada level atas, Mr. E harus berani memberikan masukan yang konstruktif terkait jalur komunikasi dan cara pengambilan keputusan dimana sering ditemukan dominasi dari beberapa anggota keluarga yang sebenarnya berada diluar struktur formal perusahaan. 
Salah satu solusi untuk permasalahan ini, Mr E. dapat mengusulkan Mrs. F dan Mr. G untuk masuk ke dalam struktur formal perusahaan sebagai
Increase urgency yang dimunculkan pada level bawah yakni mencoba menanamkan cara pandang baru yang berkaitan dengan peran vital setiap

\begin{tabular}{|c|c|c|c|}
\hline No & $\begin{array}{l}\text { Tahapan } \\
\text { Perubahan }\end{array}$ & $\begin{array}{l}\text { Managing Phase } \\
\text { (Saat ini) }\end{array}$ & $\begin{array}{l}\text { Transformation phase } \\
\text { (Akan datang) }\end{array}$ \\
\hline 1 & Kategori perusahaan keluarga & $\begin{array}{l}\text { Family } \quad \text { Business } \\
\text { Enterprise }\end{array}$ & $\begin{array}{l}\text { Family } \\
\text { Enterprise }\end{array}$ \\
\hline 2 & Keterlibatan generasi penerus & Generasi Kedua & $\begin{array}{l}\text { Generasi kedua dan } \\
\text { ketiga }\end{array}$ \\
\hline 3 & Konflik nilai dalam keluarga & Sudah ada (minim) & $\begin{array}{l}\text { Sudah ada (sering } \\
\text { terjadi) }\end{array}$ \\
\hline \multirow[t]{5}{*}{4} & $\begin{array}{l}\text { Kompetensi dan struktur } \\
\text { manajemen }\end{array}$ & & \\
\hline & $\begin{array}{l}\text { a) Keterlibatan pihak } \\
\text { luar }\end{array}$ & Sudah ada & $\begin{array}{l}\text { Sudah ada (jumlah } \\
\text { relatif banyak) }\end{array}$ \\
\hline & b) Proses rekrutmen & $\begin{array}{ll}\text { Melalui } & \text { proses } \\
\text { wawancara } & \end{array}$ & Rekrutmen terstruktur \\
\hline & c) Pembagian pekerjaan & $\begin{array}{l}\text { Mulai ada pembagian } \\
\text { kerja }\end{array}$ & $\begin{array}{l}\text { Pembagian jelas dan } \\
\text { tertulis }\end{array}$ \\
\hline & $\begin{array}{l}\text { d) Jenjang } \\
\text { karyawan }\end{array}$ & $\begin{array}{l}\text { Sudah ada (ruang } \\
\text { lingkup terbatas) }\end{array}$ & Sudah ada (terstruktur) \\
\hline \multirow[t]{4}{*}{5} & Kompensasi & & \\
\hline & $\begin{array}{l}\text { a) Gaji komisaris dan } \\
\text { deviden pemegang } \\
\text { saham }\end{array}$ & $\begin{array}{lr}\text { Komisaris } & \text { tidak } \\
\text { menuntut } & \text { return } \\
\text { jangka pendek } & \end{array}$ & $\begin{array}{l}\text { Gaji komisaris dan } \\
\text { deviden mulai } \\
\text { diimplementasikan }\end{array}$ \\
\hline & b) Gaji karyawan & Berdasarkan UMR & Diatas UMR \\
\hline & c) Bonus karyawan & $\begin{array}{l}\text { Bonus berdasar kan } \\
\text { sistem lembur }\end{array}$ & $\begin{array}{l}\text { Bonus berdasar kan } \\
\text { prestasi kerja }\end{array}$ \\
\hline \multirow[t]{5}{*}{6} & Aspek keuangan & & \\
\hline & a) Laporan keuangan & $\begin{array}{l}\text { Sudah ada (ter- } \\
\text { update secara rutin) }\end{array}$ & Sudah ada (bankable) \\
\hline & b) Pelaporan pajak & $\begin{array}{l}\text { Sudah melaporkan } \\
\text { (parsial) }\end{array}$ & $\begin{array}{l}\text { Sudah melaporkan } \\
\text { (komprehensif) }\end{array}$ \\
\hline & $\begin{array}{l}\text { c) Pemisahan } \\
\text { keuangan } \\
\text { keluarga } \\
\text { perusahaan }\end{array}$ & Mulai terpisah & Terpisah \\
\hline & $\begin{array}{l}\text { d) } \begin{array}{l}\text { Distribusi } \\
\text { pendapatan } \\
\text { keluarga dan } \\
\text { perusahaan }\end{array} \\
\end{array}$ & $\begin{array}{lr}\text { Sudah ada } & (100 \% \\
\text { pendapatan } & \text { untuk } \\
\text { perusahaan }) & \end{array}$ & $\begin{array}{l}\text { Sudah ada } \\
\text { tergantung } \\
\text { kesepakatan) }\end{array}$ \\
\hline 7 & baku perusahaan & $\begin{array}{l}\text { Sudah ada (belum } \\
\text { tertulis) }\end{array}$ & Sudah ada (tertulis) \\
\hline
\end{tabular}


paralel. Jika sebelumnya karyawan hanya dijadikan "alat" untuk mencapai tujuan perusahaan, namun saat ini karyawan lebih diposisikan sebagai partner yang bergerak bersama perusahaan. Dengan kata lain perusahaan menerapkan konsep winning together, dimana kualitas dan kinerja karyawan akan menentukan maju atau mundurnya perusahaan.

\section{Build The Guiding Team}

Pada tahap ini dibentuk sebuah tim untuk memimpin perubahan. Orangorang yang dipilih dalam tim ini harus menduduki posisi struktural di perusahaan atau minimal memiliki pengaruh dan kekuasaan, keahlian, kredibilitas serta jiwa kepemimpinan. Pada PT. Roda Bahari tim perubahan terdiri dari orang-orang yang berasal dari struktur formal perusahaan (Mr. E, Mr. H, Mr. I) serta anggota yang berasal dari luar struktur formal perusahaan (Mr. G).

\section{Get The Right Vision}

Tahap ini memerlukan sebuah visi baru untuk membantu perusahaan menentukan arah perubahan dan merumuskan strategi untuk mencapai visi tersebut.

Dalam implementasinya, tim perubahan bersama Mr. A mengembangkan visi, misi, dan struktur organisasi formal yang baru sesuai dengan rumusan strategi yang telah disusun (dalam sebuah arsitektur strategi).

\section{Communicating for Buy In}

Fokus tahapan ini berupa delivery arsitektur strategi yang merupakan output dari langkah ketiga (get the right vision) kepada level atas dan level bawah secara rutin serta berkelanjutan. Salah satu bentuk komunikasi perubahan adalah dengan memanfaatkan tim perubahan (Mr. E, Mr. G, Mr. H. Mr. I) sebagai sebuah role model untuk dijadikan contoh pada day to day activity dalam membentuk kebiasaan kerja baru bagi karyawan. Lebih lanjut, komunikasi perubahan juga dilakukan melalui rapat mingguan, bulanan, dan tahunan.

\section{Empower Action}

Tahapan ini merupakan penguatan dari proses perubahan yang telah dilakukan. Bentuk-bentuk kegiatan pada tahap ini diarahkan untuk melawan kebiasaan lama yang negatif dan hambatanhambatan tangible maupun intangible. Dalam implementasinya tim perubahan berusaha fokus pada hal-hal krusial yang mengarah pada tiga hal, yakni fundamen keuangan perusahaan, partisipasi generasi kedua dan ketiga, dan menciptakan pola kerja berdasarkan budaya baru. Detail penjabaran dari ketiga hal ini:

- Laporan keuangan yang secara rutin ter-update dan mengikuti format baku (bankable)

- Pemisahan menyeluruh antara keuangan keluarga dan perusahaan

- Distribusi pendapatan antara keluarga dan perusahaan dalam proporsi tertentu sesuai kesepakatan.

- Gaji komisaris dan deviden mulai diimplementasikan

- Pelaporan pajak secara menyeluruh

- Keterlibatan generasi kedua dan ketiga yang duduk dalam top management

- Aturan baku perusahaan sudah tertulis, seperti pembagian pekerjaan karyawan (Jobdesk) yang jelas

- Pengenalan dan penerapan budaya baru yang tercermin dalam pola kerja seperti mengedepankan kejujuran, mendorong inisiatif kerja, memunculkan ide kreatif.

\section{Create Short Term Win}

Tahapinidilakukan untuk melihat hasil nyata (keberhasilan) dari perubahan 
yang telah dilakukan selama ini. Setiap orang yang terlibat dalam proses perubahan dapat dipastikan akan terus konsisten mengikuti arah perubahan, selama keberhasilan tersebut langsung dikaitkan dengan pengakuan dan penghargaan, antara lain: penerapan insentif tetap bulanan diatas UMR; penerapan insentif tambahan berupa sistem lembur (overtime), bonus akhir tahun berdasarkan kinerja, dan bonus penyelesaian proyek.

\section{Don't Let Up}

Tahapan ini ditujukan untuk membuat proses perubahan semakin besar. Langkah untuk mewujudkan ini adalah melalui penerapan kebijakan baru dengan memanfaatkan kredibilitas yang telah terbangun. Kebijakan baru ini akan diterjemahkan dalam kegiatan-kegiatan operasional perusahaan dan pengambilan keputusan untuk hal-hal strategis. Dalam implementasinya tim perubahan fokus memperbaiki sumber daya manusia (karyawan). Tindakantindakan nyata yang dilakukan, antara lain:

- Adanya jenjang karir yang lebih terstruktur dengan adanya proyek atau bisnis baru, sehingga promosi karyawan yang memiliki kinerja baik dimungkinkan

- Keterlibatan pihak luar (karyawan baru) yang mendukung proses perubahan. Rekrutmen terhadap karyawan baru dilakukan melalui proses rekrutmen terstruktur (verifikasi berkas, psikotes dan wawancara)

- Adanya karyawan-karyawan baru memungkinkan perusahaan kedepannya memperoleh anggota tim perubahan yang baru (duplikasi).

\section{Make change stick}

Dalam tahapan akhir ini, semua hasil perubahan yang telah dilakukan dijadikan budaya kerja yang baru sehingga menciptakan kinerja dan produktivitas yang lebih baik. Dalam implementasinya, proses pembentukkan budaya baru di PT. Roda Bahari dapat dilakukan oleh tim perubahan dengan memfokuskan pada pembentukkan manajemen yang lebih efektif. Langkahlangkah untuk merealisasikan hal ini, antara lain:

- Melalui komunikasi 2 arah (level atas-level bawah-level atas)

- Pengawasan dan evaluasi terhadap aktivitas-aktivitas harian perusahaan

\section{Penutup}

Berdasarkan kajian yang telah dilakukan, diketahui bahwa saat ini PT. Roda Bahari merupakan jenis perusahaan keluarga Family Business Enterprise (FBE) yang berada dalam Managing phase. Tahapan sebelumnya yang telah perusahaan lewati adalah developing phase, sedangkan tahapan yang akan dituju adalah transformation phase dimana saat itu perusahaan sudah menjadi Family Owned Business (FOE). Merujuk pada peta stakeholder diatas, dapat diidentifikasi bahwa Mr. E selaku direktur operasional merupakan agent of change dalam proses change management, karena dinilai kompeten, terlibat langsung dalam day to day bisnis, serta memiliki akses yang cukup kepada pihak pengambil keputusan. Dalam proses pengambilan keputusan di PT. Roda Bahari sebagai perusahaan keluarga sangat dipengaruhi oleh anggota keluarga non struktural. Dengan kata lain, otoritas dan kekuasaan pada PT. Roda Bahari tidak berada dalam satu kesatuan.

Setelah dilakukan penerapan konsep change management pada perusahaan keluarga dengan teori Lewin's Three Step Model dan teori Kotter Eight Stage Change Process, terdapat benang merah dari keduanya. Pada dasarnya teori 
Kotter Eight Stage Change Process merupakan penjabaran lebih detail dari setiap tahapan dalam Lewin's Three Step Model. Penulis melakukan kategorisasi sebagai berikut: (1) Unfreezing the status quo (Increase Urgency dan Build The Guiding Team); (2) Movement to the new state (Get The Right Vision, Communicating for Buy In, dan Empower Action); (3) Refreezing (Create Short Term Win, Don't Let Up, dan Make change stick).

\section{DAFTAR PUSTAKA}

Amin M. 2009. Strategi Change Management untuk Mempercepat Implementasi Penggunaan Aplikasi Perangkat Lunak [tesis]. Jakarta (ID): Binus Business School.

Cater J, Schwab A. 2008. Turnaround strategies in established small family firms. Journal of Family Business Review, 19(1).

Jaffe DT. 2005. Strategic planning for the family in business. Journal of Financial Planning, 18(3).

[Kemenkop dan UKM] Kementerian Koperasi dan UKM. 2012. Data usaha mikro, kecil, menengah (UMKM) dan usaha besar (UB) Tahun 2011 - 2012. Jakarta (ID): Kemenkop dan UKM.

Kotter JP. 1996. Leading change. Boston (US): Hardvard Business School Press.

Li L, Xinde C. 2014. Management innovation for chinese family business. Journal of management and strategy, 5(1).

Maharani A. 2009. Kasus perubahan dalam perusahaan keluarga: PT.Solo Jaya. Jurnal Ekonomi Universitas Paramadina, 5(3).

Purhantara W. 2009. Organizational development based change management. Jurnal Ekonomi\& Pendidikan, 6(2).
Susanto AB. 2002. World class family business. Jakarta (ID): Quantum Bisnis dan Manajemen.

Utomo AS, Prastyanto I. 2009. Transforming the company making sasana husada clinic group a full family busines enterprise in the future [tesis]. Jakarta (ID): Binus Business School.

Xiongwei S. 2009. Why do change management strategies fail?. Journal of cambridge study, 4(1).

Yudhaningsih R. 2011. Peningkatan efektivitas kerja melalui komitmen, perubahan dan budaya organisasi. Jurnal Pengembangan Humaniora, 11( 1). 